\title{
Postural control in total knee arthroplasty patients with patellofemoral pain syndrome before and six months after re-operation
}

\author{
Helena Gapeyeva ${ }^{1 *}$, Tiit Haviko ${ }^{2}$, Aare Märtson², Herje Aibast', Jaan Ereline ${ }^{1}$, Mati Pääsuke ${ }^{1}$ \\ From 3rd Congress of the International Foot and Ankle Biomechanics Community \\ Sydney, Australia. 11-13 April 2012
}

\section{Background}

Although excellent long-term clinical results have been reported for the total knee arthroplasty (TKA), 37\% of patients have limited functional improvement one year after the surgery [1]. Patients with a clinical presentation of anterior knee pain could be diagnosed with patellofemoral pain syndrome (PFPS). Modified clinical classification of PFPS patients includes two main groups: with malalignment and with muscular dysfunction [2]. The aim of the study was to compare postural stability characteristics in TKA patients with PFPS before and six months after re-operation.

\section{Materials and methods}

Twelve patients aged 59-77 years with PFPS following unilateral TKA participated in the study. Pre-TKA, all patients had primary degenerative knee OA in stage III or IV (Kellgren-Lawrence Scale) and were scheduled for the first TKA. Duration of pain before TKA was 9.3 \pm 2.5 years and re-operation due to PFPS was performed 18.8 \pm 3.5 months later. Patella malalignment was noted in eight patients and patella altered position in three patients. Static standing balance was assessed by centre of foot pressure (COP) sway registered during $30 \mathrm{~s}$ quiet bipedal standing with eyes open on twin force plates Kistler 9286A (Switzerland) using Sway software of motion analysis system Elite (BTS S.p.A., Italy). Plantar pressure distribution was recorded by Digital Biometry Scanning System and Milletrix software (DIASU, Italy). Data are means and standard errors of means $( \pm$ SE).

\footnotetext{
* Correspondence: helena.gapeyeva@ut.ee

${ }^{1}$ Institute of Exercise Biology and Physiotherapy, University of Tartu, Tartu 51014, Estonia

Full list of author information is available at the end of the article
}

Table 1 Plantar pressure distribution (weight ratio \%) in TKA patients with PFPS before and 6 months after reoperation

\begin{tabular}{|c|c|c|c|c|}
\hline \multicolumn{2}{|c|}{ Characteristics } & \multirow{2}{*}{$\begin{array}{l}\begin{array}{l}\text { Before re- } \\
\text { operation }\end{array} \\
66.37 \pm 4.90\end{array}$} & \multirow{2}{*}{$\begin{array}{l}\begin{array}{l}\text { After re- } \\
\text { operation }\end{array} \\
51.55 \pm 1.64\end{array}$} & \multirow{2}{*}{$\begin{array}{l}\mathbf{p} \\
0.02\end{array}$} \\
\hline FOREFOOT & PFPS leg & & & \\
\hline & $\begin{array}{l}\text { Non-PFPS } \\
\text { leg }\end{array}$ & $64.15 \pm 6.47$ & $52.16 \pm 3.40$ & NS \\
\hline \multirow[t]{2}{*}{ REARFOOT } & PFPS leg & $44.85 \pm 1.75$ & $51.54 \pm 1.86$ & 0.021 \\
\hline & $\begin{array}{l}\text { Non-PFPS } \\
\text { leg }\end{array}$ & $49.16 \pm 3.36$ & $47.84 \pm 3.40$ & NS \\
\hline
\end{tabular}

\section{Results}

COP sway trace radius of PFPS leg was significantly shorter 6 month after re-operation as compared before it (5.91 \pm 0.48 and $4.22 \pm 0.22 \mathrm{~mm}$, respectively, $\mathrm{p}=0.007$ ). No significant difference was found in COP trace length and velocity as compared pre- and post-surgery data ( $>0.05$ ). Significant decrease of plantar pressure distribution in forefoot of PFPS leg was noted $(\mathrm{p}<0.05$, Table 1$)$.

\section{Conclusions}

Main findings of our study were: (1) postural control in TKA patients with PFPS significantly improves (and 2) re-distribution of plantar pressure from forefoot to rearfoot in PFPS leg takes place 6 months after re-operation. The link between the segmental configuration of the lower limbs was described [3] and the importance of paying attention to balancing of the PF soft tissues was emphasized in studies of PF pain after TKA [4].

\section{Acknowledgements}

This study was supported by Estonian Ministry of Education and Research project No SF0180030s07 and Estonian Science Foundation project No 7939. 


\section{Author details}

${ }^{1}$ Institute of Exercise Biology and Physiotherapy, University of Tartu, Tartu

51014, Estonia. ${ }^{2}$ Department of Traumatology and Orthopaedics, University

of Tartu, Tartu 51014, Estonia.

Published: 10 April 2012

\section{References}

1. Franklin PD, Li W, Ayers DC: The Chitranjan Ranawat Award: functional outcome after total knee replacement varies with patient attributes. Clin Orthop Relat Res 2008, 466:2597-2604.

2. Witvrouw $E$, et al: Clinical classification of patellofemoral pain syndrome: guidelines for non-operative treatment. Ortopedia Biomeccanica, Riabilitazione Sportiva. 7 Corso Internazionale. Assisi, 21-23 novembre 2003 Universita degli Studi - Azienda Ospedaliera, Perugia; 2003, 174-186.

3. Roudiger PR: Relative contribution of the pressure variations under the feet and body weight distribution over both legs in the control of upright stance. J Biomech 2007, 40:2477-2482.

4. Scuderi GR, Insall JN, Scott NW: Patellofemoral pain after total knee arthroplasty. J Am Acad Orthop Surg 1994, 2:239-246.

doi:10.1186/1757-1146-5-S1-033

Cite this article as: Gapeyeva et al:: Postural control in total knee arthroplasty patients with patellofemoral pain syndrome before and six months after re-operation. Journal of Foot and Ankle Research 20125 (Suppl 1):033.

\section{Submit your next manuscript to BioMed Central and take full advantage of:}

- Convenient online submission

- Thorough peer review

- No space constraints or color figure charges

- Immediate publication on acceptance

- Inclusion in PubMed, CAS, Scopus and Google Scholar

- Research which is freely available for redistribution

Submit your manuscript at www.biomedcentral.com/submit 